\title{
SELECTION OF CARRY IDLERS SPACING OF BELT CONVEYOR TAKING INTO ACCOUNT RANDOM STREAM OF TRANSPORTED BULK MATERIAL
}

\section{DOBÓR ROZSTAWU KRĄŻNIKÓW GÓRNYCH PRZENOŚNIKA TAŚMOWEGO Z UWZGLĘDNIENIEM LOSOWO ZMIENNEJ STRUGI UROBKU*}

\begin{abstract}
The study on the design optimisation of belt conveyors used in the mining industry - the proper selection of carry idlers - aiming to decrease the specific energy consumption of transportation with regard to different operational conditions is presented. High capacity overburden belt conveyors from a surface lignite mine as well as copper ore ones from underground ines are analysed. Calculations are performed in the specialised engineering software with the use of characteristics of idlers' rotational resistance as a function of radial loading that were obtained in the laboratory and identified distribution of actual capacity of main haulage and division belt conveyors. The purposefulness of the individual treatment to the carry idler spacing, depending on the conveyor's location within the haulage system and its operational loadings - bigger for the main haulage and smaller for the division conveyors is found. The presented results of calculations are evidences for further economic analysis, which take into account-apart of energy costs - also costs of installation and replacements of idlers.
\end{abstract}

Keywords: belt conveyor, idlers spacing, working loadings, energy consumption.

\begin{abstract}
Przedstawiono studium optymalizacji konstrukcyjnej - właściwego doboru rozstawu krążników górnych - górniczych przenośników taśmowych, pod kątem zmniejszenia zużycia jednostkowej energii transportu z uwzględnieniem zróżnicowanych warunków eksploatacyjnych. Analizowano przenośniki nadkładowe dużej wydajności z kopalni odkrywkowej węgla brunatnego i podziemne z kopalni rud miedzi. Obliczenia wykonano w środowisku specjalistycznego oprogramowania inżynierskiego wykorzystujac wyznaczone laboratoryjnie charakterystyki oporu obracania krążników w funkcji obciążenia oraz zidentyfikowane rozkłady strugi urobku w odstawie głównej i oddziałowej. Stwierdzono celowość zróżnicowania rozstawu zestawów krążników górnych w zależności od rzeczywistego obciążenia strugą urobku - większego dla przenośników odstawy głównej (zbiorczych) i mniejszego dla przenośników oddziałowych. Przedstawione wyniki obliczeń sa przesłankami do analiz ekonomicznych, uwzględniających - oprócz kosztu energii - również koszt zabudowy $i$ wymian krą̇ników.
\end{abstract}

Stowa kluczowe: przenośnik taśmowy, rozstaw krążników, obciążenia robocze, badania, zużycie energii.

\section{Introduction}

In carry belt on a conveyors is usually supported with three-roller idlers, installed at a fixed spacing distance of 0.8 to 2.5 meters along the whole conveyor route. Idlers are therefore the most numerous element of a conveyor that is crucial for its reliability and energy efficiency. In the mines with belt conveyor transport, users and constructors attention is focused on main elements deciding of the costs: conveyor belt and idlers. The savings may be sought, as in case of the other means of transport, in the precise selection of conveyor equipment considering the properly identified transport requirements.

Well-known method of cutting the energy consumption and reducing the capital or operational costs is enlarging the idler sets spacing. In some version of long range conveyors, the idler sets located ever more than $3.0 \mathrm{~m}$ from each other, are installed. These are, however, specific construction use under stable loading from transported material, ensuring the predictable load of idlers [9]. In mine haulage systems the variability of actual capacity is much bigger, what, for a long period of mine, was the reason for common usage of oversized conveyor constructions. But, the compilation of tests results of high capacity conveyor idlers in Rhineland Basin [1] with operation data has enabled to verify the concept of upper idlers spacing [5].
The experiences were used to analyze the selection of upper idler sets of conveyors, use also in Polish mining [6], taking also into consideration, experimentally determined characteristics of idlers rotating resistance in the function of temporary yield [14] and calculated, expected life-time of idlers in the real operational conditions $[3,11,12$, 18]. The analysis of the optimal carry idlers spacing is based on the identified total resistances to motion $[4,21]$ and on idlers rotational resistance with regard to the distribution of transported bulk material $[2,10,13]$. The criteria used for optimal selection of idlers spacing are: the specific energy consumption i.e. energy per unit of route length and unit of capacity [5] as well as predicted number of annual idler sets replacement. The second criterion is defined as a quotient of total number of installed sets and calculating the lifetime of idlers set, estimated basing on minimal life of roller in the idler [3].

The basic tool used for the optimisation analysis is the in-house computer system QNK-TT [16], supported with advanced computing algorithms for calculating primary resistances to motion of a belt conveyor with regard to belt parameters, characteristics of transported material as well as construction and operational parameters of conveyor [4]. The concept of adjusting the distance between upper idler sets to the real operational loads requires exact calculations of movement resistance generated on the idler set $[4,21]$ and identification of the

(*) Tekst artykułu w polskiej wersji językowej dostępny w elektronicznym wydaniu kwartalnika na stronie www.ein.org.pl 
distribution of transported bulk material stream $[2,13]$. This identification is more and more reliable due to implementation of IT systems, collecting complex data (technical, operational, diagnostic) about the transport system of the mine $[7,8,19,22]$. Automated data processing gives the credible evaluation of conveyor elements condition [17], and additionally, supported by results of simulatory calculations [16], allows to reduce, the assumed so far, construction margin, without prejudice for safety and reliability of belt conveyors utilization.

Summary of the to date attempts of the selection of upper idler set spacing in the mine belt conveyors, typical for the biggest belt transport systems i.e. haulage of overburden in lignite open-pit mine and haulage of copper ore in KGHM Polska Miedź SA mine, was made in the paper. For the both systems, typical conveyors were chosen, used alternatively for diversified transport task, representing the work with full load (main transport - conveying the collective stream of the output from several mine district) and with partial load (local transport conveying the output from one mining division, with typical, numerous operation periods without load). These conveyors were equipped alternatively with standard idler sets as well as with modified ones, having reduced rotation resistance. For those route configurations and conveyor positions within the transport system, variants of upper idler sets spacing, for which changes of construction would not be necessary, were checked.

\section{Simulation tests for belt conveyors used in open-pit mines}

The presented considerations concerning the optimal support of carry belt strand, concerned the biggest conveyors, used for output haulage, where the belt width is $2.25 \mathrm{~m}$, and in carry belt strand, idlers having $\varnothing$ of $194 \mathrm{~mm}$ and casing length of $800 \mathrm{~mm}$, are used. Two types of idlers were taken into consideration - standard and modernized ones, for which characteristics of rotating resistance as square function of radial load, were determines [11, 14] (fig.1). They were used as virtual methods for calculating the movement resistance in simulating calculations cycle.

In optimization analyzes, identification of operational capacity in the given transport system is necessary [10]. For selected locations of conveyors in the transport system of open-pit mine:

- major haulage (combined) - conveyor hauling the overburden from several mining levels,

- division haulage - conveyor taking the material from one level (from single excavator)

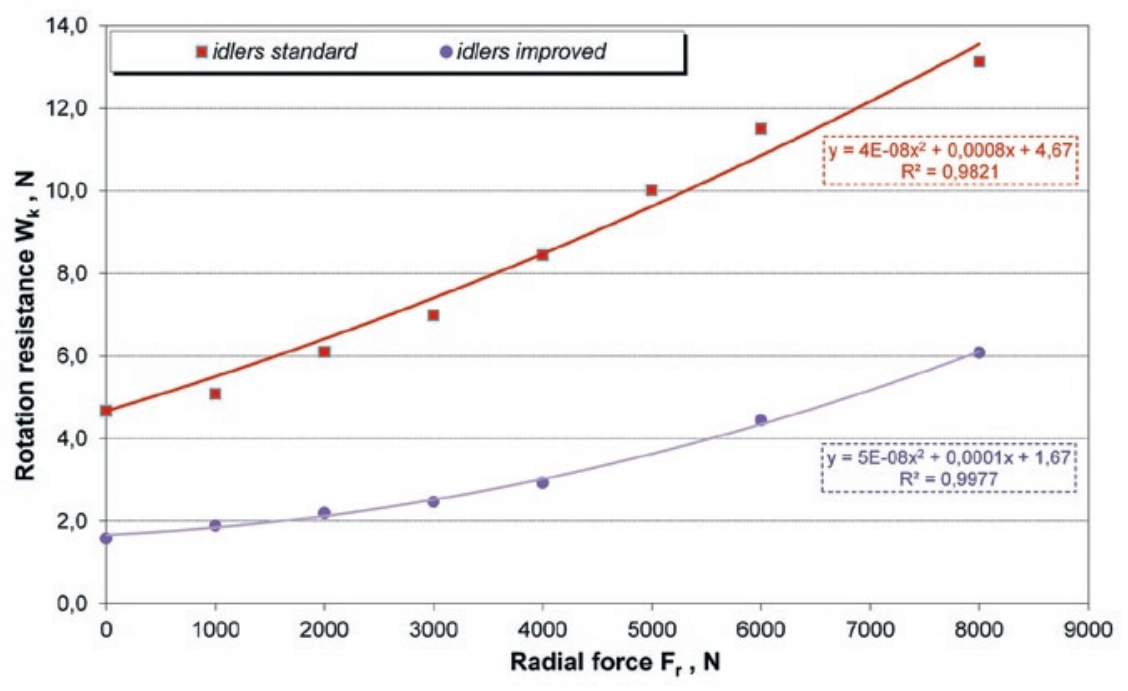

Fig. 1. Average resistance of $\varnothing 194 \times 670 \mathrm{~mm}$ idlers rotation $\mathrm{Wk}$ in function of radial force $-\mathrm{Fr}$ obtained (calculated) for standard and modernized idler.
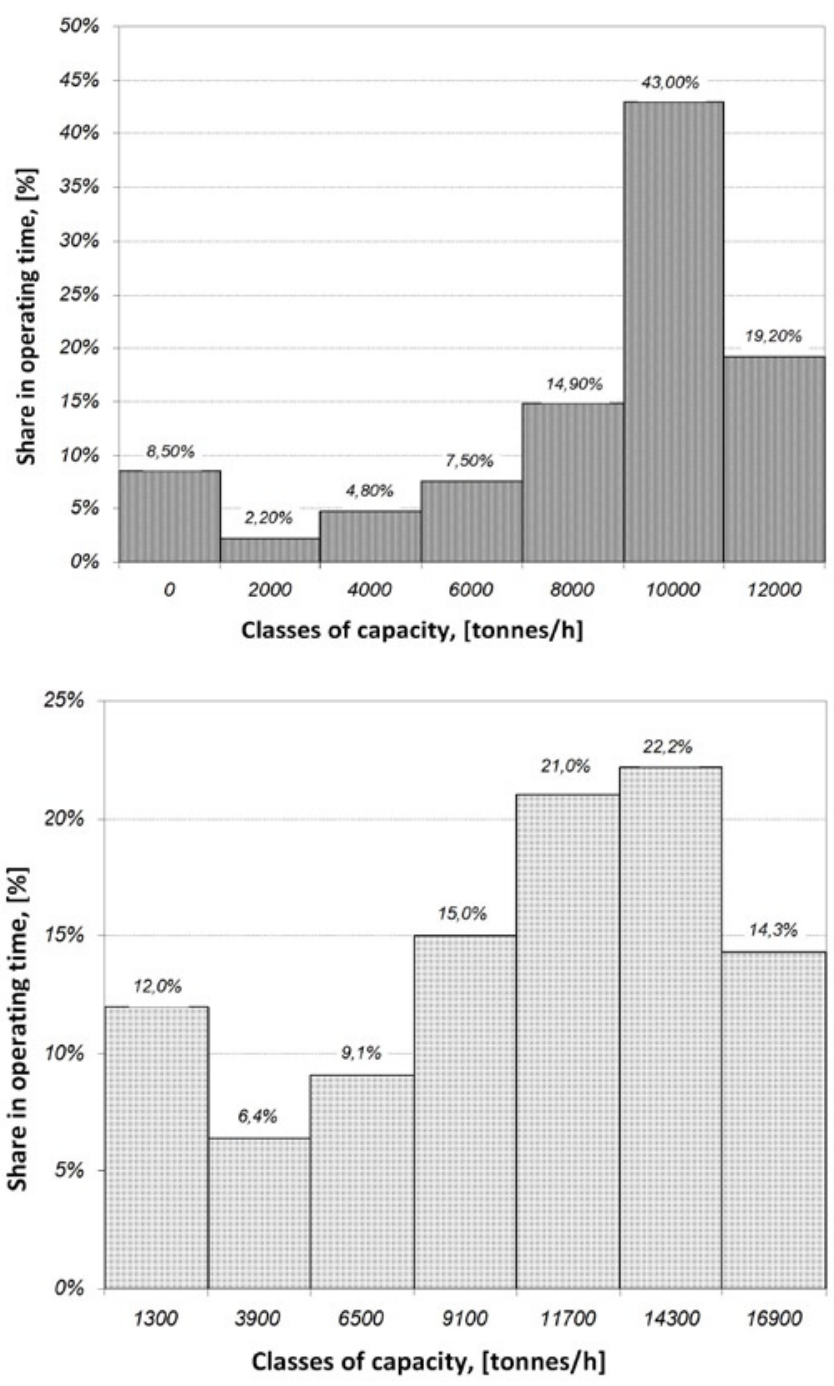

Fig. 2. Histograms of recorded temporary capacities of overburden: a) from a single excavator, b) on a main haulage conveyor

the histograms of instantaneous capacity of the transported overburden stream, representing real distribution of output load on the idler sets in carry belt strand of conveyor, were made (fig.2).

In spite of random nature of output stream, the analyses considered the seasonal impact of ambient temperature on resistances to motion of conveyor. Thus, the calculations were made for three distinguished season temperatures, taking into consideration average monthly 24 hours temperatures on Polish Lowland. The results were presented as weighted mean for calculative temperature of conveyor operation (tab.1).

Figure 3 present calculated specific energy consumption (SEC) index in carry belt strand of overburden conveyor, depending on temporary value of capacity, equal the radial load of idlers. In the case of standard idlers, within the whole range of load, the SEC value for $1.45 \mathrm{~m}$ distance is slightly lower that for the most often used in Polish lignite mines, distance of $1.2 \mathrm{~m}$. In the case of modernized idlers, having lower rotation resistances (fig.1), these char- 
Table 1. Major calculating parameters of high capacity belt conveyor

\begin{tabular}{|c|c|}
\hline Parameter & Open-pit conveyor \\
\hline Transported output, density, kg/m $\mathrm{m}^{3}$ & Overburden, 1700 \\
\hline Calculating work temperature, ${ }^{\circ} \mathrm{C}$ & 0 (45\%), $11(25 \%), 19(30 \%)$ \\
\hline Length, m; gradient & 1205; levels \\
\hline Belt width, mm & 2250 \\
\hline Belt; cover plates, mm & St $3150 ; 14+7$ \\
\hline Belt speed, $\mathrm{m} / \mathrm{s}$ & 5.98 \\
\hline Spacing of upper idles sets, $\mathrm{m}$ & Variants: $1.2 ; 1.45$ \\
\hline Rotation resistance of upper idler, $\mathrm{N}$ & $\begin{array}{l}\text { According to quoted character- } \\
\text { istics }\end{array}$ \\
\hline Calculating capacity, t/h & $100-18000$ \\
\hline Note & $\begin{array}{l}\text { Belt tension settled for maximum } \\
\text { load }\end{array}$ \\
\hline
\end{tabular}

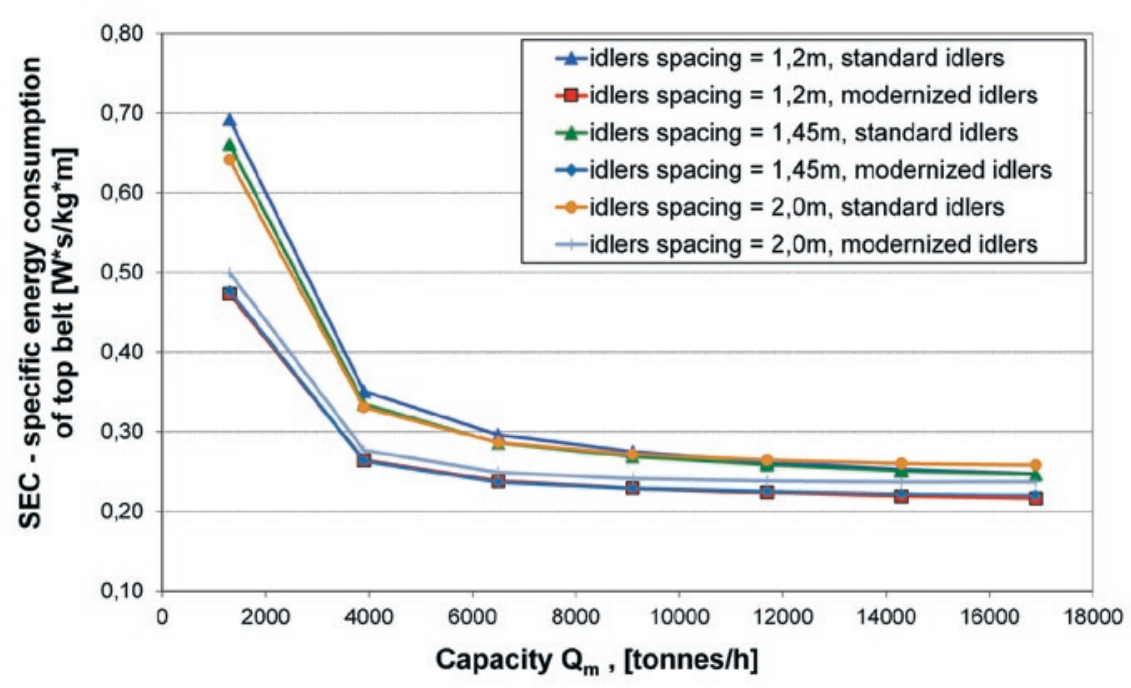

Fig. 3. Specific energy consumption (SEC) in top belt as a function of actual capacity of a belt conveyor (conveyor parameters in tab.1)

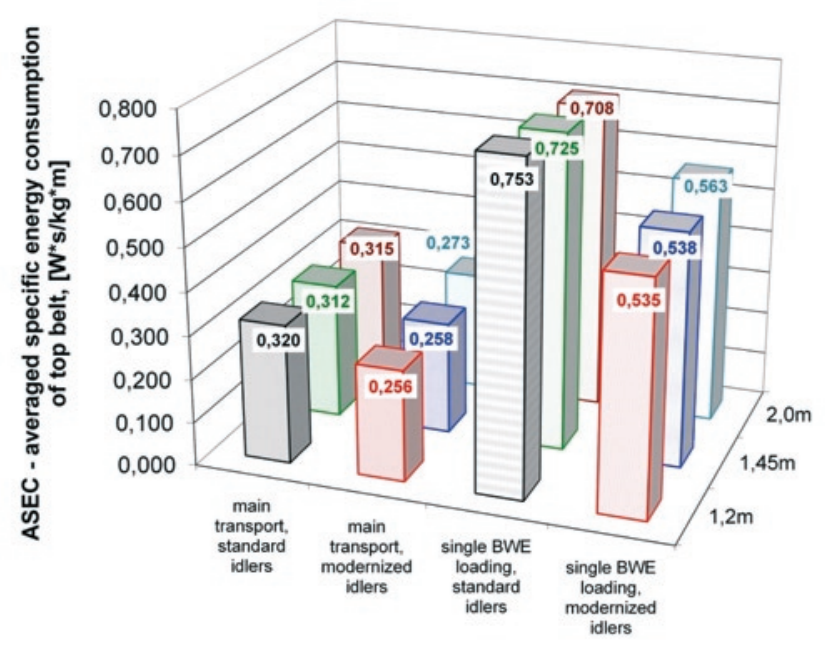

Fig. 4. Averaged specific energy consumption (ASEC) in top belt of a main and secondary transportation overburden belt conveyor with regard to carry idlers spacing

acteristics are almost the same, what is caused by lower contribution of this constituent in total movement resistance.
Table 2. Expected number of idlers replaced per year (per $1 \mathrm{~km}$ of a conveyor route)

\begin{tabular}{||c|c|c||}
\hline \hline Carry belt idlers spacing, $m$ & main haulage & single BWE loading \\
\hline 1,2 & 104 & 52 \\
\hline 1,45 & 172 & 86 \\
\hline 2,0 & 250 & 167 \\
\hline
\end{tabular}

From the perspective of using the specific transport system, more vital are the average values of specific energy consumption, complying with typical, for the facility, load of transported material stream, described by capacity distribution (fig. 2). The result of average specific energy consumption in top belt strand, distinguishing the alternative spacing of carry idler sets for the conveyor of major haulage (combined) and for the division haulage conveyor (taking the output from one chain and bucket excavator) are presented on figure 4 .

Division conveyor (taking the output from one excavator) works under much lower average load, but has a significant part of idle running (fig.2), thus, the clearly higher values of specific energy consumption than in case of main haulage conveyor, are not surprising. It can be concluded, from diagram no. 4 , that the increase of carry idlers spacing (from the standard $1.2 \mathrm{~m}$ to $1.45 \mathrm{~m}$ ) should give the savings in energy consumption for division conveyors and, in fact, will not affect the energy consumption of main haulage conveyors. The spacing of $2.0 \mathrm{~m}$ increases the SEC of the main haulage conveyor while in the case of division conveyors the SEC depends on the type of idlers. The considered increase of carry idlers spacing reduces their total number which, due to the increase of radial loading (different for main haulage and division conveyors) affects the estimated increase of number of idler sets replaced every year (tab.2).

The economic analyze of calculation results concerning specific energy consumption and number of idlers replacement is not presented, since it depends on operation costs of the mine and can be made only having such data.

3. Simulation tests for conveyors used in underground mine

The necessity of reducing the mining costs, increasing distance of underground transportation routes in copper ore mines as well as more frequent usage of long belt conveyors form main coal haulage in hard coal mines together with the observed improvement of technical culture of conveyors operation $[8,22]$ give grounds for investigating the possibility of upper idlers sets optimization, on those conveyors. One should remember, that conveyors in underground mines have bigger construction reserves, which are used to prevent the failures caused by objective operational difficulties in tight mine workings.

Published results of detailed tests of rotation resistance of carry idlers in conveyors designed for underground mines $[14,15]$ in connection with analyzes of variable transported material streams in those mines (fig. 6) [13], enable to carry out the study of carry idler selection for underground copper ore haulage. The tests results confirmed the dependence between idler rotation resistance and the radial force. As a result of laboratory tests, the individual characteristics of carry idlers as a square function were calculated (fig.5), which were used then in the module for calculation the conveyor movement resistance - method of primary resistances QNK-TT software.

As demonstrated the long-term measurements of temporary capacity, made in the underground copper mine [13], division and main 


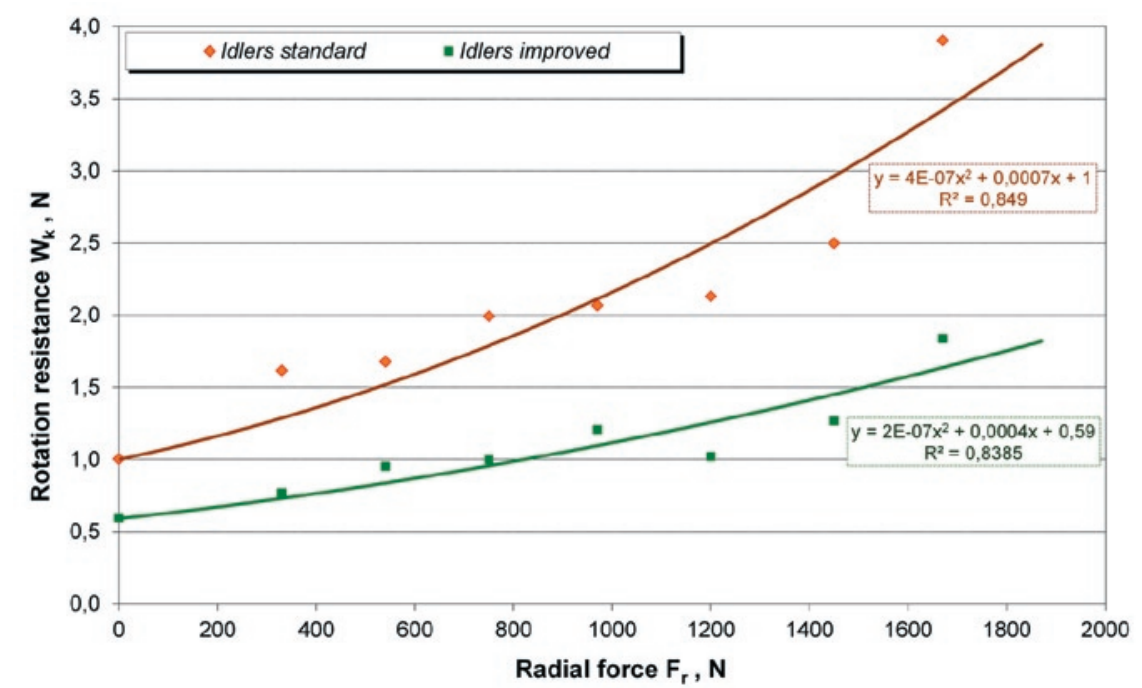

Fig. 5. Average rolling resistance of idler $\varnothing 133 \times 370 \mathrm{~mm}$ depending of radial force for standard and modernized rollers
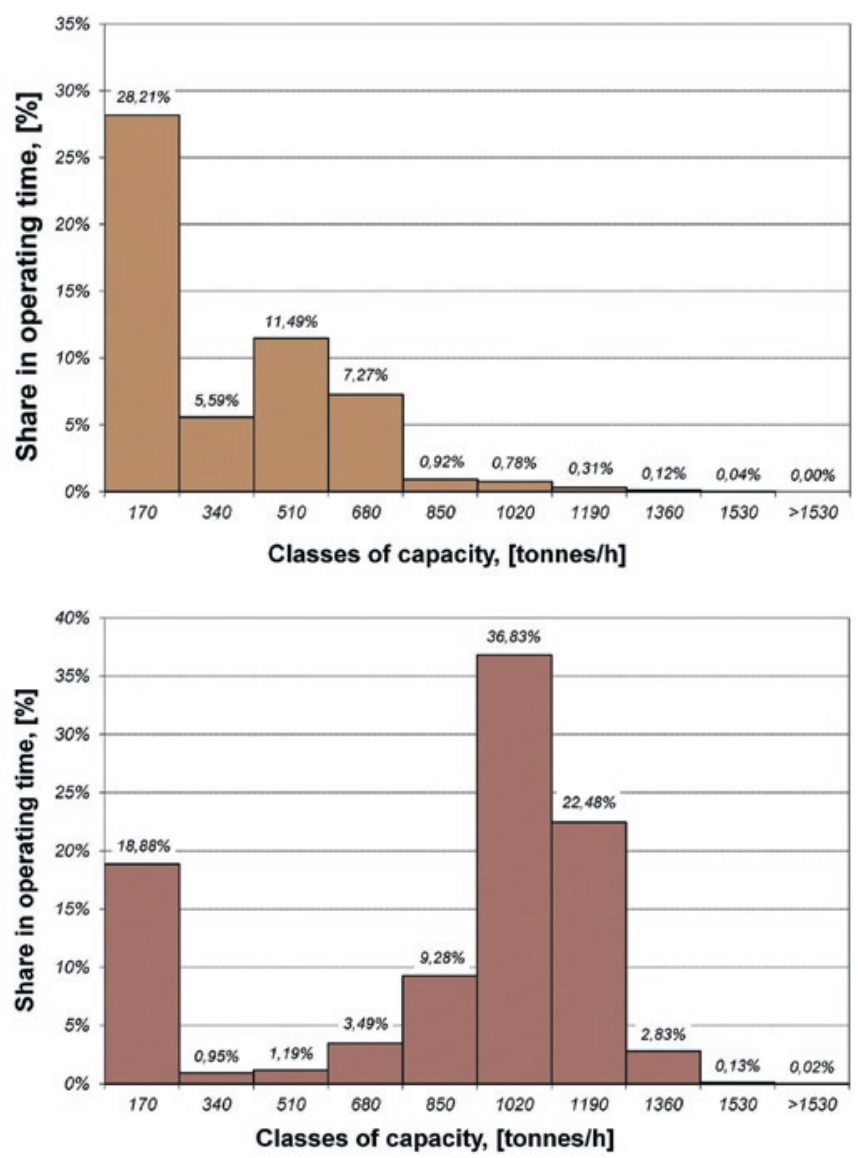

Fig. 6. Example histograms of mass capacity of conveyors used in KGHM PM.S.A underground copper mine: a) division haulage conveyor, b) main haulage conveyor

conveyors have different characteristics of the stream of output being hauled (fig. 6).

Using the division ore bunkers makes possible to differentiate the operating time of the division and main haulage conveyors. It is estimated that main haulage conveyors work ca. 6 thousand hour per year, while the division ones - ca. 4 thousand hours. This difference has the impact on evaluating the lifetime of upper idler sets.
For the analyses, variant values of upper idler sets spacing, were taken, i.e. from 0.83 to $1.66 \mathrm{~m}$, which application does not require the construction changes. Other parameters of conveyor are standard ones (tab. 3).

Underground conveyors operate, in fact, in constant, high temperature, which is favorable to obtain the low value of idlers rotation resistance (fig. 5). On both below diagrams (fig. 7) the calculated index of specific energy consumption - SEC, in upper belt strand of underground conveyor, is presented, depending on temporary capacity, equal the radial load of standard idlers (fig. 7a) and modernized, with reduced energy consumption (fig. 7b). Characteristic is the intersection of the specific energy consumption curves. For the small load by output stream, the more favorable is bigger spacing of upper idles, while for bigger load - the smaller one. Therefore, there is no possibility to give the general answer, which spacing of upper sets will reduce the energy consumption costs. Calculating the average

Table 3. Selected parameters of tested underground conveyors

\begin{tabular}{||c|c||}
\hline Parameter & Underground conveyor \\
\hline Transported output, density, $\mathrm{kg} / \mathrm{m}^{3}$ & Copper ore, 1700 \\
\hline Calculating work temperature, ${ }^{\circ} \mathrm{C}$ & 25 \\
\hline Length, $\mathrm{m}$; gradient & 1500 ; horizontal \\
\hline Belt width, $\mathrm{mm}$ & 1000 \\
\hline Belt; covers thickness, $\mathrm{mm}$ & Slow-burning, EP2000/4 6+3; \\
\hline Belt speed, $\mathrm{m} / \mathrm{s}$ & 2,8 \\
\hline Spacing of carry idlers, $\mathrm{m}$ & $\begin{array}{c}\text { Variants: } 0.83 ; 1.25 ; 1.66 \\
\text { istics }\end{array}$ \\
\hline Rotation resistance of upper idler $\mathrm{N}$ & $\begin{array}{c}\text { According to quoted character } \\
\text { id } 1400\end{array}$ \\
\hline Calculating capacity, $\mathrm{t} / \mathrm{h}$ & $\begin{array}{c}\text { Belt tension settled for maximum } \\
\text { load }\end{array}$ \\
\hline Note &
\end{tabular}

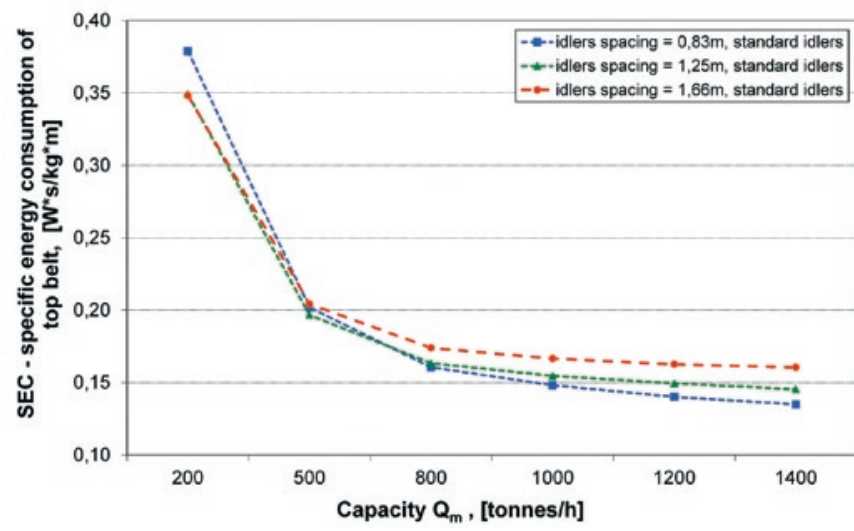

Fig. 7a. Specific energy consumption (SEC) in top belt as a function of actual capacity of an uderground belt conveyor for copper ore transportation (conveyor parameters in tab.3): a) standard idlers

specific energy consumption, in accordance with identified load of main and division conveyors, suggests maintaining rather the standard spacing $(0.83 \mathrm{~m})$ for the main ones and possible increase of spacing (up to $1.25 \mathrm{~cm}$ ) for the less loaded, division ones (fig. 8). 


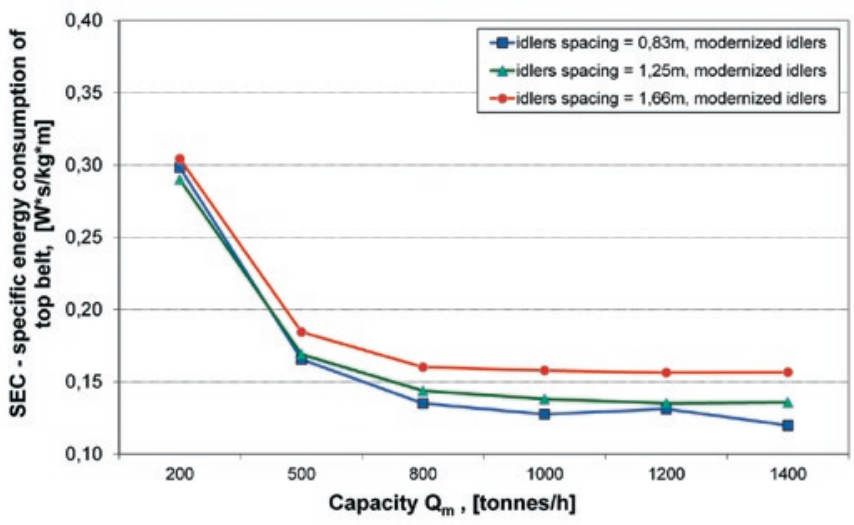

Fig. 7b. Specific energy consumption (SEC) in top belt as a function of actual capacity of an uderground belt conveyor for copper ore transportation (conveyor parameters in tab.3): b) modernized idlers

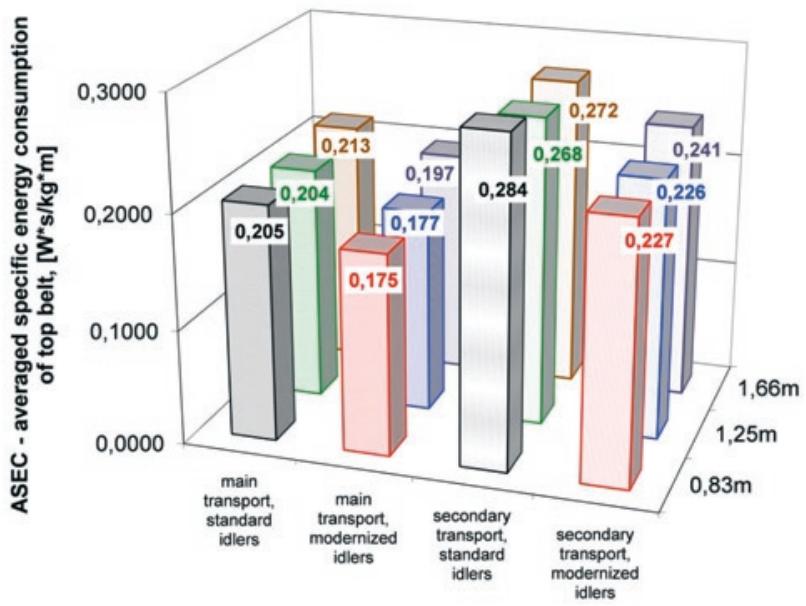

Fig. 8. Averaged specific energy consumption (ASEC) in top belt of a main and secondary transportation underground belt conveyor with regard to top belt idlers spacing

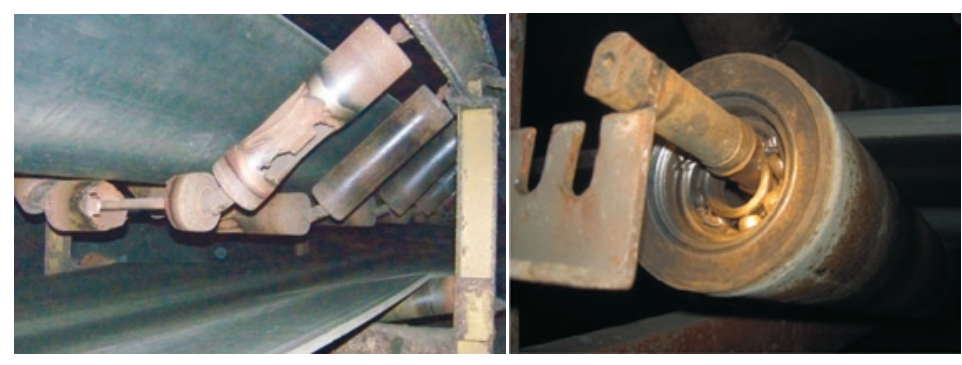

Fig. 9. Examples of premature wear of idlers [10]
Table 4. Number of idlers replaced per year (per $1 \mathrm{~km}$ of conveyor route)

\begin{tabular}{|c|c|c||}
\hline Idlers spacing & main transport & secondary transport \\
\hline 0.83 & 21 & 10 \\
\hline 1.25 & 47 & 23 \\
\hline 1.66 & 86 & 40 \\
\hline
\end{tabular}

Similarly, as in the case of open-pit conveyors, the extension of distance between idler sets causes the increase in radial load (different for main and division haulage conveyors), what has the impact on the estimated growth of number of idler sets replaced every year (tab. 4). It should be emphasized that in the underground mine, the corrosion seizing of bearings or coating erasure are the reasons of premature wear of idlers (fig. 9) [10] and thus they do not reach the assumed lifetime resulting from the operational loads [3].

\section{Conclusions}

The results of considerations about typical conveyors, operating in the open-pit lignite mine and in the underground copper mine, show that some $2-3 \%$ of energy savings are possible due to the optimized carry idlers spacing. Seeking the optimal solutions for the criteria of specific energy consumption and the expected number of idlers replacements requires taking into account both the identified resistances to motion and the knowledge about the random stream of transported bulk material.

Non-linear characteristics of idlers rotation resistance and identified, different stream of material, transported on main haulage and division conveyors, indicate that the individual treatment to the idler spacing in carry belt strand, depending on the conveyors location within the haulage system and on accessibility of components - sets of standard or modernized idlers, is necessary.

The calculation results evidence that for the overburden conveyor, with 2.25 wide belt, it is advisable, especially in case of conveyors taking the output from one excavator - enlarging the standard spacing from 1.2 to 1.45 or even up to 2.0 meters both for standard and for modernized idlers (with reduced rotation resistance).

In underground conveyors, with $1.0 \mathrm{~m}$ wide belt, designed for copper ore transport, it is also possible to enlarge the standard idler sets spacing from $0.83 \mathrm{~m}$ to $1.25 \mathrm{~m}$. In the case of main haulage it gives the savings only in reduction of the number of installed idlers, but for less loaded division conveyors, in addition the energy savings may be expected.

\section{Acknowledgements:}

This paper was financially supported partly by the Polish Ministry of Science and Higher Education as scientific project No $\mathrm{S40111}$

\section{References}

1. Bukowski J., Gładysiewicz L., Król R. Tests of belt conveyor resistance to motion. Eksploatacja i Niezawodnosc - Maintenance and Reliability 2011; 3: 17-25.

2. Dworczyńska M., Gładysiewicz L, Król R. Model transportowanego urobku dla szacowania trwałości krążników. Transport Przemysłowy i Maszyny Robocze 2013; 1(19):22-26.

3. Geesmann F.O. Experimentale und Theoretische Untersuchungen der Bewegungswiderstände von Gurtfördenanlege. Praca doktorska. Universität Hannover 2001; (niepublikowana).

4. Gładysiewicz L., Hardygóra M., Kawalec W. Determining belt resistance. Bulk Handling Today 2009; 5: 23-28.

5. Gładysiewicz L., Kawalec W. Carrying idler spacing with regard to the distribution of conveyed stream. Bulk Solids Europe 2010: International Conference on Storing, Handling and Transporting Bulk, Glasgow, Scotland, September 9-10, 2010 / Vogel Business Media, Institution of Mechanical Engineers. 
6. Gładysiewicz L., Kawalec W. Dobór rozstawów krążników górnych nowej generacji w przenośnikach nadkładowych dużej wydajności. Transport Przemysłowy Maszyny Robocze 2011; 3(13):7-10.

7. Hardygóra M. et al. Comprehensive studies on the multi-criterial effectiveness of large belt conveyor transportation system. Proceedings of the Twentieth International Symposium on Mine Planning and Equipment Selection, MPES 2011, Almaty, October 12-14, 2011:881-895.

8. Kacprzak M., Kulinowski P., Wędrychowicz D. Computerized information system used for management of mining belt conveyors operation. Eksploatacja I Niezawodnosc - Maintenance and Reliability 2011; 2(50): 81-93.

9. Kawalec W. Przenośniki taśmowe dalekiego zasięgu. Transport Przemysłowy 2003; 1(11):13-20.

10. Król R. Metody badań i doboru elementów przenośnika taśmowego z uwzględnieniem losowo zmiennej strugi urobku. Oficyna Wydawnicza Politechniki Wrocławskiej 2013.

11. Król R. Ocena trwałości krążników dla rzeczywistych obciążeń przenośnika taśmowego. Przegląd Górniczy 2011; nr 11:82-90.

12. Król R., Gładysiewicz L. Kompleksowa ocena jakości krążników poliuretanowych stosowanych w górnictwie odkrywkowym. Prace Naukowe Instytutu Górnictwa Politechniki Wrocławskiej. Studia i Materiały 2009, 36:19-31.

13. Król R., Gładysiewicz L., Wajda A. Analiza rozkładu obciążeń krążników nośnych w kopalniach rud miedzi. Transport Przemysłowy i Maszyny Robocze 2010; 2(8):19-31.

14. Król R, Kisielewski W. Urządzenie do badania oporów obracania krążników pod obciążeniem. Zgłoszenie patentowe nr P406829 z dn. 13.01.2014.

15. Król R, Kisielewski W. Wpływ krążników na energochłonność przenośnika taśmowego. Mining Science 2014; 21(2):61-72.

16. Kulinowski P. - Simulation studies as the part of an integrated design process dealing with belt conveyor operation, Eksploatacja Niezawodnosc - Maintenance and Reliability 2013; 15 (1):83-88.

17. Lodewijks G. Strategies for AutomatedMaintenance of Belt Conveyor Systems. BulkSolids Handling 2004, 24 (1):16-22.

18. Łagoda T., Sonsino C.M. Comparison of different methods for presenting constant and variable amplitude loading fatigue results. Materialwissenschaft und Werkstofftechnik 2004; Vol.35, No.1:13-20, http://dx.doi.org/10.1002/mawe.200300692.

19. Mazurkiewicz D. Computer-aided maintenance and reliability management systems for conveyor belts. Eksploatacja i Niezawodnosc Maintenance and Reliability 2014; 16 (3): 377-382.

20. Pang Y., Lodewijks, G. The application of RFID technology in large-scale dry bulk material transport system monitoring. Environmental Energy and Structural Monitoring Systems (EESMS), IEEE, 2011: 1-5.

21. Qing H., Daqian D. Zirui H., Dongmei D. Analytical Model between Power and Idler Spacing of Belt Conveyor. Second International Conference on Computer Modeling and Simulation 2010: 8-10.

22. Stefaniak P., Zimroz R., Król R., Górniak-Zimroz J., Bartelmus W., Hardygóra M. Some Remarks on Using Condition Monitoring for Spatially Distributed Mechanical System Belt Conveyor Network in Underground Mine - A Case Study. Condition Monitoring of Machinery in Non-Stationary Operations. Springer 2012:497-507.

\section{Lech GŁADYSIEWICZ \\ Witold KAWALEC \\ Robert KRÓL}

Faculty of Geoengineering, Mining and Geology

Wroclaw University of Technology

Wybrzeze Wyspianskiego 27, 50-370 Wroclaw, Poland

E-mail: lech.gladysiewicz@pwr.edu.pl, witold.kawalec@pwr.edu.pl, robert.krol@pwr.edu.pl 